\title{
Floristic composition and spatial distribution of vascular epiphytes in the restingas of Maracanã, Brazil
}

\author{
Adriano Costa Quaresma ${ }^{1,2}$ and Mário Augusto Gonçalves Jardim ${ }^{1}$
}

Received: 30 October, 2012. Accepted: 19 November, 2013

\begin{abstract}
Vascular epiphytes constitute a life form that is important to maintaining the biological diversity of forest ecosystems, because they provide food resources and specialized microenvironments for fauna in the forest canopy. This study aimed to describe the floristic composition and ecological aspects of vascular epiphytes occurring in the restingas (coastal woodlands) within the Algodoal-Maiandeua Environmentally Protected Area, located in the municipality of Maracanã, in the state of Pará, Brazil. We sampled five $50 \times 50 \mathrm{~m}$ plots (three in dry restinga forest and two in floodplain restinga forest), the sampled area therefore totaling $1.25 \mathrm{ha}$. In the plots sampled, vascular epiphytes were identified and described according to their frequency, abundance, importance value (IV), functional group and vertical distribution (trunk, lower crown or upper crown of the host). For both forest types, we identified 477 individuals belonging to five families, nine genera and 11 species. The most species-rich families were Araceae and Orchidaceae. The species with the highest density, frequency and IV were the secondary hemiepiphytes Philodendron acutatum, Anthurium pentaphyllum and Philodendron muricatum, collectively accounting for $92.1 \%$ of all sampled individuals. The true epiphytes predominated. Epiphytic species richness and abundance was greater on the host trunk than in the lower or upper crown. The seasonal climate and structure of the forest favored greater abundance of secondary hemiepiphytes and a higher frequency of epiphytes on the trunks of their hosts.
\end{abstract}

Key words: functional group, Amazon coast, epiphytism, vertical distribution

\section{Introduction}

The restingas (coastal woodlands) of Brazil feature a mosaic of vegetation formations, floristic compositions and structures, from herbaceous to shrub and even forest, which often are in close proximity to each other (Martins et al. 2008; Menezes et al. 2010). In the Amazon region, restingas occupy an estimated area of only $1000 \mathrm{~km}^{2}$, which corresponds to less than $0.1 \%$ of all vegetation types (Amaral $e t$ al. 2008). Nevertheless, little is known about the floristic composition and ecology of the restingas.

The vascular epiphytes compose a guild that is characterized by the use, throughout part or all of their life, of a host tree, from which they do not derive nutrients, the host providing them only with mechanical support (Madison 1977; Giongo \& Waechter 2004; Ribeiro 2009; Mania \& Monteiro 2010). These epiphytes provide food resources and specialized microenvironments for canopy fauna, such as birds (Nadkarni \& Matelson 1989), mollusks (Mazella \& Russo 1989) and ants (Dejean et al. 1995), as well as providing a refuge for the reproduction of many species of animals (Benzing 1986).
Another aspect is the rapid capture of matter and energy with their subsequent reintegration into the ecosystem; although it does not exceed $2 \%$ of the dry mass of forests, the photosynthetic biomass of epiphytes often equals and occasionally exceeds that of their hosts (Nadkarni 1984; Kersten 2010).

Epiphytes are classified, on the basis of their functional group, as follows (Benzing 1990): true epiphytes (which typically begin and end their lives on a host tree); facultative epiphytes (which can grow epiphytically or on the forest floor); accidental epiphytes (which are usually terrestrial but can occasionally be epiphytic); primary hemiepiphytes (which begin their lives on a host tree and subsequently send down aerial roots to obtain nutrients from the soil); secondary hemiepiphytes (which germinate in the soil and, after establishing contact with a host plant, allow the basal portion of their root system and stem to degenerate).

Another aspect of epiphytes is their vertical distribution, which can vary, in terms of the number of individuals and number of species, from the base to the crown of the host tree (Waechter 1998). This variation can be influenced by the shape, texture of the bark and height of the host tree,

\footnotetext{
${ }^{1}$ Museu Paraense Emílio Goeldi, Coordenação de Botânica, Belém, PA, Brazi
}

${ }^{2}$ Author for correspondence: acq.quaresma@gmail.com 
as well as by the temperature, humidity and light intensity (Kersten et al. 2009).

The existing knowledge of the floristic composition and ecology of vascular epiphytes in forest formations of the restingas in Brazil has been obtained primarily from studies conducted in the southern region (Waechter 1998; Kersten \& Silva 2001; Kersten et al. 2009) and southeastern region (Ribeiro 2009; Mania \& Monteiro 2010). Those studies have cited Orchidaceae, Bromeliaceae and Polypodiaceae as the most representative families and have identified true epiphytes as constituting the dominant functional group. However, data regarding vertical distribution are conflicting. For example, Kersten \& Silva (2001) observed that epiphytic species richness and abundance were greatest on the host trunk, whereas Ribeiro (2009) found those values to be greatest in the lower crown of the host.

Within the Brazilian Amazon, located in the north of the country, studies of the epiphytic flora have been conducted in the savanna, known as the cerrado (Gottsberger \& Morawetz 1993) in upland forests (Pos \& Sleegers 2010), in open rain forests (Obermüller et al. 2012) and in lowland forests, the last focusing on epiphytic orchids (Medeiros \& Quaresma 2009; Medeiros \& Jardim 2011) or epiphytic bromeliads (Quaresma \& Medeiros 2009; Quaresma \& Jardim 2012). In the restinga within the Algodoal-Maiandeua Environmental Protection Area (APA) alone, Amaral et al. (2008; 2009) recorded nine species, whereas Costa (2009) recorded two species, in sand dunes and shrublands. Therefore, the lack of data on vascular epiphytes in the Amazon, especially in restinga ecosystems, calls for further studies of their flora and ecology, in order to promote the creation of strategies for their conservation.

Considering the environmental importance of vascular epiphytes and the lack of knowledge about epiphytes in restinga forest formations, the present study focused on the floristic composition and ecology of vascular epiphytes occurring in restingas within the Algodoal-Maiandeua APA, with the objective of answering the following questions: "Is there a difference among forests in terms of their epiphytic communities?" "Which epiphytic species predominate?" "Are there differences among strata, in terms of their occupation by epiphytes?" "What are the main functional groups of epiphytes?" We tested the hypothesis that forests differ in terms of the composition of their epiphyte communities, the families Orchidaceae, Bromeliaceae and Polypodiaceae dominating, epiphytes preferentially colonizing the lower crown of their host trees and true epiphytes being the predominant functional group.

\section{Material and methods}

The Algodoal-Maiandeua APA is located in the municipality of Maracanã ( $00^{\circ} 38^{\prime} 29^{\prime \prime}$; $\left.47^{\circ} 31^{\prime} 54^{\prime \prime} \mathrm{W}\right)$, which is on the northeastern coast of Pará, a state located in the north of Brazil, within the Amazon biome. According to the Köppen system of classification, the climate of the region is type Aw (tropical wet and dry, or savanna), with minimum and maximum annual average temperatures of $25.2^{\circ} \mathrm{C}$ and $31.7^{\circ} \mathrm{C}$, respectively, and average annual rainfall of approximately $2800 \mathrm{~mm}$ (Bastos \& Lobato 1996). In the Algodoal-Maiandeua APA, the vegetation types are: mangrove, early successional forest, salt marsh, shrubland, beach/barrier dune, sand dune field, interdune flat and, to a lesser extent, forest (Senna \& Bastos 2009).

$>$ The forest formations of the Algodoal-Maiandeua APA restinga were described based on Amaral et al. (2008) and Senna \& Bastos (2009), as well as through in situ observations: Dry restinga forest

- flat to undulating topography

- quite sandy soil, $\mathrm{pH} 4.95$, containing 69.46 g. $\mathrm{kg}^{-1}$ of organic matter, $12.58 \mathrm{mg} \cdot \mathrm{dm}^{-3}$ of phosphorus, $0.83 \mathrm{~g} . \mathrm{kg}^{-1}$ of nitrogen and $69.5 \mathrm{mg} . \mathrm{dm}^{-3}$ of iron

- intermediate light intensity

- high leaf biomass on the soil

- dominance of Anacardium occidentale L., Pouteria ramiflora (Mart.) Radlk., Pradosia pedicellata (Ducke) Ducke and Myrcia rufipila McVaugh.

$>$ Floodplain restinga forest

- flat topography with some depressions that are occasionally flooded, mainly during the rainy season - slightly sandy soil, $\mathrm{pH} 4.36$, containing 57.67 g.kg-1 of organic matter, $2.58 \mathrm{mg} . \mathrm{dm}^{-3}$ of phosphorus, $0.83 \mathrm{~g} . \mathrm{kg}^{-1}$ of nitrogen and $7.5 \mathrm{mg} . \mathrm{dm}^{-3}$ of iron

- shaded, with low light intensity

- high leaf biomass on the soil

- dominance of Virola surinamensis (Rol. ex Rottb.) Warb., Symphonia globulifera L. f., Macrolobium pendulum Willd. ex Vogel and Euterpe oleracea Mart.) which are species characteristic of other wetlands in the Amazon biome (Jardim \& Vieira 2001; Batista et al. 2011; Maués et al. 2011).

The soil fertility analysis was provided by the project "Scientific research and local training as sustainable indicators for environmental restoration of the flora of the Algodoal-Maiandeua APA, Maracanã, Pará, Brazil", funded by the Brazilian National Council for Scientific and Technological Development.

Between August 2011 and January 2012, we delineated three plots of $50 \times 50 \mathrm{~m}$ each (total area, $0.75 \mathrm{ha}$ ) in dry restinga forest ( $00^{\circ} 35^{\prime} 15.2^{\prime \prime} \mathrm{S} ; 47^{\circ} 34^{\prime} 21^{\prime \prime} \mathrm{W}, 00^{\circ} 35^{\prime} 8.4^{\prime \prime}$ ' $; 4^{\circ} 34^{\prime} 24.7^{\prime \prime} \mathrm{W}$, and $00^{\circ} 36^{\prime} 10.0^{\prime \prime}$ ' $; 47^{\circ} 34^{\prime} 2.8^{\prime \prime} \mathrm{W}$, respectively) and two plots of $50 \times 50 \mathrm{~m}$ each (total area, $0.50 \mathrm{ha}$ ) in floodplain restinga forest $\left(00^{\circ} 36^{\prime} 34.1^{\prime \prime} \mathrm{S} ; 47^{\circ} 34^{\prime} 39.3^{\prime \prime} \mathrm{W}\right.$ and $00^{\circ} 36^{\prime} 35.5^{\prime \prime} \mathrm{S} ; 4^{\circ} 34^{\prime} 34.2^{\prime \prime} \mathrm{W}$, respectively). Therefore, the total area of forest sampled was 1.25 ha. Within the plots sampled, we recorded all vascular epiphytes and their respective host trees (including only trees with a diameter at breast height $\geq 5 \mathrm{~cm}$ ).

When possible, vascular epiphytes and their hosts were identified in situ with the aid of a parabotanist. When in 
situ identification was not possible, individuals were photographed or botanical material was collected. Either of both were used for subsequent confirmation by the use of dichotomous keys, reference to the literature, consultation with experts or comparison with specimens in the collection of the João Murça Pires Herbarium of the Museu Paraense Emílio Goeldi (code, MG). When necessary, binoculars and free climbing were used for better visualization of epiphytic species.

The epiphytic species were classified according to the functional group categories adopted by Benzing (1990): true epiphytes, facultative epiphytes, accidental epiphytes, primary hemiepiphytes and secondary hemiepiphytes. To evaluate the vertical distribution of the epiphytic species, we employed an adapted version of the method described by Gonçalves \& Waechter (2002), dividing each host tree into three strata: the trunk (defined as the base region of the host tree up to the height of the first major branch); the lower crown (from the first major branch up to the middle of the major branches); and the upper crown (the remaining branches). The stratification of the host trees was performed in order to facilitate the counting of the specimens, as well as to identify any preferences of epiphytes for specific strata.

For the epiphytes, the importance values (IVs) were estimated on the basis of the absolute and relative frequencies for individual host trees and for host tree species, taking as individuals each clump that was spatially isolated (Waechter 1998), without considering the number of constituent rosettes (Bromeliaceae) or the number of pseudobulbs (Orchidaceae). For Araceae species, all spatially isolated stems were considered as individuals.

To test the differences among the communities, we randomly selected 100 host trees within each of the two forest types. We then constructed similarity matrices, using the Bray-Curtis index as a distance measure, based on the abundance data for each individual tree and using host trees as sampling units. Finally, we performed ordination analysis using nonmetric multidimensional scaling (NMDS). To assess the significance of the clusters formed in the NMDS and to identify the species that contributed most to the differences between the two main study areas, we performed analysis of similarities and similarity percentages analysis, respectively.

The evaluation of differences in abundance among the strata host trees was calculated by the nonparametric Kruskal-Wallis test using the program Systat 11.0. The ordination technique (NMDS), analysis of similarities and similarity percentages analysis were performed by the program R (R Development Core Team; http://www.r-project.org/).

\section{Results}

The two main forest areas studied showed considerable differences in terms of the epiphytic species composition: five $(45.4 \%)$ of the 11 species identified occurred only in the dry restinga forest; two species (18.1\%) occurred only in the floodplain restinga forest; and four species (36.3\%) were common to both forest types. That result was confirmed by the NMDS ordination analysis (Fig. 1), which grouped the forests into distinct clusters that were statistically different $(\mathrm{R}=0.45, \mathrm{p}=0.001)$. The species that contributed most of the differences between the two areas were Philodendron muricatum Willd. ex Schott (95.73\%) in the floodplain restinga forest; and Philodendron acutatum Schott (53.86\%) and Anthurium pentaphyllum (Aubl.) G.Don. (45.42\%) in the dry restinga forest.

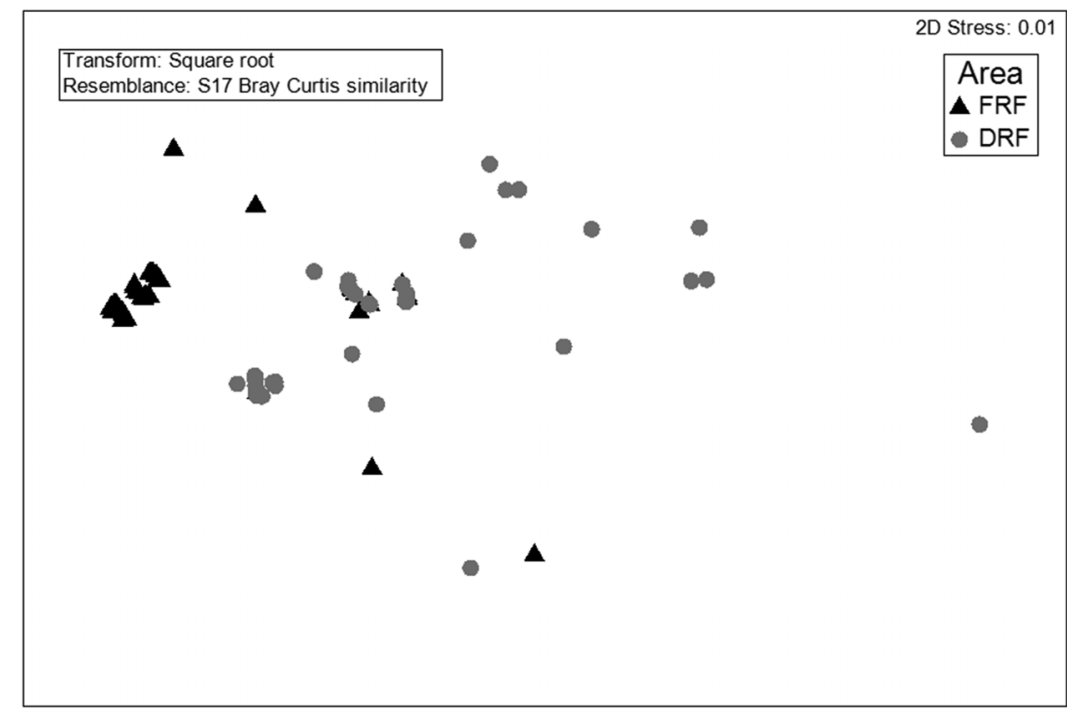

Figure 1. Nonmetric multidimensional scaling ordination analysis showing the clustering patterns of the sampling units (host trees) in dry restinga forest (DRF) and floodplain restinga forest (FRF) within the Algodoal-Maiandeua Environmentally Protected Area, in the municipality of Maracanã, located in the state of Pará, Brazil. 
We identified a total of 477 epiphytic individuals, within five families, nine genera and 11 species. The most well-represented families were Araceae and Orchidaceae, with four species each (Tab. 1). The largest number of individuals was found for Philodendron muricatum $(\mathrm{n}=179)$ corresponding to $37.4 \%$ of the total, followed by Anthurium pentaphyllum $(\mathrm{n}=139 ; 29.0 \%)$ and Philodendron acutatum $(\mathrm{n}=123 ; 25.7 \%)$. Therefore, those three species, all of which belong to the family Araceae, collectively accounted for $92.1 \%$ of the individuals sampled.

In the dry restinga forest, we identified 242 individual vascular epiphytes, within five families, eight genera and nine species, occupying a total of 113 host trees. The families Orchidaceae and Araceae had the highest species richness (with four and two species, respectively), followed by Bromeliaceae, Clusiaceae and Polypodiaceae, with one species each. The species with the largest number of individuals were Anthurium pentaphyllum and Philodendron acutatum, with 137 and 75, respectively.

In the floodplain restinga forest, we identified 235 individual vascular epiphytes, within three families, five genera and six species, occupying a total of 141 host trees. Araceae had the highest species richness (with four species), followed by Bromeliaceae and Orchidaceae, with one species each. The species with the largest number of individuals were Philodendron muricatum and Philodendron acutatum, with 179 and 27 , respectively.

The true epiphytes constituted the dominant functional group (with six species; 54.5\%), followed by secondary hemiepiphytes (with four species; $36.3 \%$ ), and primary hemiepiphytes (with one species; 9.1\%). The families Orchidaceae, Bromeliaceae and Polypodiaceae presented exclusively true epiphytes, whereas the family Araceae presented primary and secondary hemiepiphytes. We identified no accidental epiphytes.
Species richness was highest on the host trunk, where we recorded 10 species, four of which were exclusive to that stratum. In the lower crown, we recorded six species, only one of which was exclusive to that stratum, whereas we recorded only two species in the upper crown, where there were no exclusive species. As can be seen in Tab. 2, the number of individuals was highest on the trunk $(\mathrm{n}=$ $324)$, followed by the lower crown $(\mathrm{n}=114)$ and upper crown $(\mathrm{n}=39)$. However, the difference in abundance among the strata was not significant for the dry restinga forest $\left(\mathrm{H}_{(2,139)}=5.101059, \mathrm{p}=0.0780\right)$ or for the floodplain restinga forest $\left(\mathrm{H}_{(2,219)}=1.132585, \mathrm{p}=0.5676\right)$. The epiphytic species with the highest IVs were Philodendron acutatum $(\mathrm{IV}=33.76)$, Anthurium pentaphyllum $(\mathrm{IV}=30.75)$ and Philodendron muricatum (IV = 25.57).

\section{Discussion}

The forest formations studied differed considerably in terms of their epiphytic species composition, presenting many species that were unique to certain areas. That was corroborated by the low proportion of shared species (only 36.3\%) and by the NMDS analysis, which separated the host trees into clusters according to their occupation, principally, by the most abundant epiphytic species in each forest. Therefore, the host trees on which only Anthurium pentaphyllum occurred were clustered to the left of the graph, and those on which only Philodendron muricatum occurred were clustered to the right. These results are similar to those found by Martins et al. (2008) in an area of restinga in the municipality of Bertioga, in the Brazilian state of São Paulo, where the authors identified various epiphytic species that were unique to both types of restinga forest, which also had very few species in common. This highlights the importance of conservation of these environments, especially

Table 1. List of species and functional groups of vascular epiphytes occurring in dry restinga forest and floodplain restinga forest in the Algodoal-Maiandeua Environmentally Protected Area, in the municipality of Maracanã, located in the state of Pará, Brazil.

\begin{tabular}{|c|c|c|c|c|c|}
\hline Family & Species & FG & DRF & FRF & Total \\
\hline \multirow{4}{*}{ Araceae } & Anthurium pentaphyllum (Aubl.) G.Don. & SHE & 137 & 2 & 139 \\
\hline & Monstera subpinnata (Schott) Engl. & SHE & 0 & 4 & 4 \\
\hline & Philodendron acutatum Schott & SHE & 75 & 48 & 123 \\
\hline & Philodendron muricatum Willd. ex Schott & SHE & 0 & 179 & 179 \\
\hline Bromeliaceae & Aechmea tocantina Baker & $\mathrm{TE}$ & 2 & 1 & 3 \\
\hline Clusiaceae & Clusia columnaris Engl. & PHE & 1 & 0 & 1 \\
\hline \multirow{4}{*}{ Orchidaceae } & Catasetum discolor (Lindl.) Lindl. & $\mathrm{TE}$ & 1 & 1 & 2 \\
\hline & Epidendrum nocturnum Jacq. & $\mathrm{TE}$ & 15 & 0 & 15 \\
\hline & Epidendrum strobiliferum $\mathrm{Rchb} . \mathrm{f}$. & $\mathrm{TE}$ & 1 & 0 & 1 \\
\hline & Cohniella cebolleta (Jacq.) Christenson & TE & 7 & 0 & 7 \\
\hline Polypodiaceae & Serpocaulon triseriale (Sw.) A.R. Sm. & TE & 3 & 0 & 3 \\
\hline
\end{tabular}

EC - functional group; DRF - restinga forest of drought; FRF - floodplain restinga forest; TE - true epiphytes; PHE - primary hemiepiphytes; SHE - secondary hemiepiphytes. 
Table 2. Vascular epiphyte species sampled, in descending order by importance value, as well as absolute and relative frequency of individual host trees and host tree species, in dry and floodplain restinga forests in the Algodoal-Maiandeua Environmentally Protected Area, in the municipality of Maracanã, located in the state of Pará, Brazil.

\begin{tabular}{lcccccccc}
\hline Species & T & LC & UC & AFi & RFi & AFj & RFj & VI \\
\hline Philodendron acutatum & 73 & 39 & 11 & 31.40 & 28.42 & 65.15 & 39.09 & 33.76 \\
Anthurium pentaphyllum & 131 & 8 & - & 39.83 & 36.05 & 42.42 & 25.45 & 30.75 \\
Philodendron muricatum & 94 & 57 & 28 & 33.43 & 30.26 & 34.85 & 20.91 & 25.57 \\
Epidendrum nocturnum & 9 & 6 & - & 1.74 & 1.58 & 9.09 & 3.64 & 2.62 \\
Cohniella cebolleta & 7 & - & - & 1.16 & 1.05 & 6.06 & 2.73 & 1.89 \\
Aechmea tocantina & 2 & 1 & - & 0.87 & 0.79 & 4.55 & 2.73 & 1.76 \\
Catasetum discolor & 2 & - & - & 0.58 & 0.53 & 3.03 & 1.82 & 1.17 \\
Monstera subpinnata & 4 & - & - & 0.58 & 0.53 & 3.03 & 0.90 & 0.72 \\
Serpocaulon triseriale & 1 & 2 & - & 0.29 & 0.26 & 1.52 & 0.90 & 0.59 \\
Clusia columnaris & 1 & - & - & 0.29 & 0.26 & 1.51 & 0.90 & 0.59 \\
Epidendrum strobiliferum & - & 1 & - & 0.29 & 0.26 & 1.51 & 0.90 & 0.59 \\
\hline
\end{tabular}

$\mathrm{T}$ - trunk; LC - lower crown; UC - upper crown; AFi - absolute frequency of individual host trees; RFi - relative frequency of individual host trees; AFj - absolute frequency of host tree species; $\mathrm{RFj}$ - relative frequency of host tree species; $\mathrm{VI}$ - importance value.

the floodplain restinga forest in the Algodoal-Maiandeua APA, which covers a smaller area than do other vegetation formations and yet has many unique species.

The fact that Orchidaceae showed the greatest species richness in the dry restinga forest also contributed to the separation between the two forest types in the NMDS analysis. This difference between the dry and floodplain restinga forests, in terms of the species composition of epiphytic orchids, has also been reported for areas of restinga in the Brazilian state of Santa Catarina by Fraga \& Peixoto (2004). Among those areas of restinga, the authors found that epiphytic orchid species richness was greater in coastal dune forests (dry forest and Myrtaceae forest) than in floodplain and flooded forests. They proposed that, although the upwelling of groundwater (i.e., a rise in the water table) is not an important factor in the selection of epiphytic orchids, it seems to play a role in the selection of host trees.

In the present study, the fact that epiphytic species composition differed between the dry and floodplain restinga forests might be related to the difference between the two types of forests, in terms of the host tree species presented. In dry restinga forests, representatives of the family Myrtaceae predominate (Amaral et al. 2008), whereas floodplain restinga forests, possibly due because of the prolonged period of flooding, are dominated by tree species typical of the Amazon lowlands (Jardim \& Vieira 2001; Batista et al. 2011; Maués et al. 2011). This differentiated tree flora can lead to distinct epiphytic flora, because characteristics intrinsic to host trees, such as the moisture retention, chemical composition and morphology of the bark, can influence the occurrence of vascular epiphytes (Kersten 2010).

The epiphytic species richness observed in the present study was low in comparison with that reported in other studies conducted in restinga forests (Waechter 1998; Kersten \& Silva 2001; Martins et al. 2008; Ribeiro 2009;
Mania \& Monteiro 2010). This low richness is characteristic of forests with a seasonal climate, where the rainfall occurs primarily at certain times of the year and there is a well-defined dry season. According to Gentry \& Dodson (1987), seasonality is a critical factor in the establishment and development of epiphytes.

The fact that the vascular epiphyte species richness found in the restingas of the northern state of Para was lower than that reported for restingas in the southern and southeastern regions of the country might also be related to the proximity of the latter with the Atlantic Forest, which is a diversity hotspot for several families, such as Orchidaceae (Cunha \& Forzza 2007) and Bromeliaceae (Wanderley et al. 2007), which are cited as the most diversified in the canopies of tropical forests (Waechter 1998; Ceja-Romero et al. 2010).

The species composition by family observed in the present study followed a worldwide trend of many species concentrated within a few families. For example, we found that $66.6 \%$ of the species identified belonged to Orchidaceae or Araceae, which are cited by Kersten (2010) as being the most diversified families of epiphytes. This was also demonstrated in the studies conducted by Nieder et al. (2000), Gonçalves \& Waechter (2002), Giongo \& Waechter (2004), Kersten \& Kunyioshi (2006) and Cervi \& Borgo (2007), all of whom identified Orchidaceae as the dominant family, as well as in that conducted by Benavides et al. (2005), who identified Araceae as the dominant family.

Floristic studies have demonstrated that the families Orchidaceae, Bromeliaceae and Polypodiaceae show the greatest species richness in areas of restinga (Waechter 1998; Kersten \& Silva 2001; Ribeiro 2009; Mania \& Monteiro 2010). However, in the present study, only Orchidaceae was among the richest families. In a study conducted in areas of restinga within the Atlantic Forest, Kersten (2010) reported that Bromeliaceae was the most species-rich family, due to 
the high number of Vriesea species and greater diversity of genera. However, in the present study, we identified only one species of Bromeliaceae, representing, together with Polypodiaceae, one of the least species-rich families in the forest formations evaluated.

These differences in species richness and family richness between the restingas along the Amazon coast and restingas in other coastal areas of Brazil were previously described by Amaral et al. (2008). The authors compared the floristic composition of the restingas along the Amazon coast with that of restingas along the coast of the state of Rio de Janeiro and found that the number of species in the latter was nearly three times higher than that observed for the former, as well as that the most well-represented families in one were represented by few species in the other. However, it is of note that this comparison was based on other plant groups (mainly trees) and included few vascular epiphytes.

With respect to the functional groups, the predominance of true epiphytes has been reported in studies evaluating other forest environments, such as Araucaria forest (Kersten \& Silva 2002; Hefler \& Faustioni 2004; Kersten \& Kunyioshi 2006; Buzatto et al. 2008), deciduous forest (Rogalski \& Zanin 2003), semideciduous forest (Dettke et al. 2008; Bonnet et al. 2011) and floodplain forest (Zotz \& Schultz 2007). Such predominance has also been reported in other studies of restinga forests (Kersten \& Silva 2001; Ribeiro 2009; Mania \& Monteiro 2010). However, the proportion of true epiphytes observed in the present study was low compared with that reported in the works cited above $(54.5 \%$ vs. 70 $80 \%)$. Therefore, it is possible that the climate of the region, which features a well-defined dry period, is a limiting factor in the establishment and development not only of epiphytes in general but also of true epiphytes in particular, whose representatives complete their life cycle without contact with the soil and suffer from a lack of water (water stress), which is considered one of the greatest difficulties in surviving above the ground (Laube \& Zotz 2006). The climate can also favor the occurrence of secondary hemiepiphytes, which, despite being less well-represented in terms of the number of species, accounted for $93 \%$ of the individuals sampled. Therefore, the water stress generated by the dry season can favor species that germinate in the soil and subsequently rely on a host tree for support, thereby bypassing this environmental adversity, which is considered the most important abiotic factor affecting the growth of epiphytes (Kersten 2010). The sandy soil of the restingas, which absorbs water rapidly and does not allow significant evaporation, might also favor species that occur on the forest floor (Kersten \& Silva 2001).

Although we found no statistical difference between strata in terms of species abundance, there were differences in terms of species richness. Waechter (1998) also found that the vertical distribution of epiphytic species differs, in number of individuals and number of species, along the length the host tree. These patterns are influenced by factors that differ from the soil to the forest canopy, such as light and moisture, forming a microclimatic gradient that influence the distribution of epiphytic species along the length the host tree (Kersten \& Silva 2001).

Within a forest, the intensity of light decreases progressively from the canopy to the forest floor, whereas humidity progressively increases (Mania 2008). The lower light intensity and higher humidity in the understory, combined with the accumulation of nutrients around the base of the host trees, favors the development of shade-loving species (Brown 1990), which could explain the higher number of species observed on the host trunk.

Greater epiphytic species richness on the trunk of the host tree is not a pattern found for all environments. Even among similar environments, the results regarding the vertical distribution of epiphytes are conflicting. This becomes clear when we analyze other studies conducted in restinga forests, where Mania (2008) and Kersten \& Silva (2001) found epiphytic species richness to be greatest on the trunk of the host tree, whereas Ribeiro (2009) found it to be greatest in the lower crown of the host. In Araucaria forest, Fraga et al. (2008) found epiphytic species richness to be greatest on the trunk, whereas Kersten \& Silva (2002) found it to be greatest in the lower crown. Epiphytic species richness has been found to be greatest on the host trunk in areas of Atlantic Forest (Bonnet \& Queiroz 2006), as well as at sites with varying degrees of disturbance (Bataghin et al. 2010), whereas it has been found to be greatest in the lower crown of hosts in gallery forests (Giongo \& Waechter 2004) and in floodplain forests of the Amazon estuary (Pos \& Sleegers 2010; Medeiros \& Jardim 2011). Therefore, different ecosystems have distinct patterns of vertical distribution of epiphytes, which underscores the importance of increasing the knowledge of the ecology of the various functional groups in each environment.

In the present study, epiphytic species richness in the lower crown was intermediate between that observed for the other two strata. In comparison with the trunk, the crown (upper and lower) receives more light and presents a greater accumulation of debris from the canopy; however, the branches of the lower crown are older and thicker than are those in the upper crown, and it is therefore expected that there would be more epiphytic species and individuals in the lower crown (Kersten 2006). However, canopy height and the lack of a defined intermediate forest stratum with higher light intensity (Kersten \& Silva 2001) might have resulted in our species counts being highest in the lower strata, the trunk in this case.

In the upper crown, where the epiphytic species richness was lowest, the number of branches available for attachment is greater. However, as discussed by Kersten \& Silva (2001), that stratum does not allow the development of many species, because of mechanical, spatial and temporal issues. In the upper crown, the branches are generally slender, the light intensity is high, the humidity is probably low, and the winds, coming from the ocean, are stronger than in the other strata. 
Philodendron acutatum, which had the highest IV in the present study, presents a wide geographic distribution, occurring from northern South America to southern Brazil (Sakuragui 2001), indicating its high adaptability to different environments and, consequently, to different host tree species. The species was cited for the Venezuelan Amazon (Nieder et al. 2000) and the Colombian Amazon (Benavides et al. 2005), although there were only 1 and 14 individuals, respectively, identified in the forests evaluated. Although Sakuragui (2001) recognized the Amazon basin as one of the centers of diversity for the genus Philodendron, that does not seem to be true for restingas within the region, where we found only two species of the genus.

Anthurium pentaphyllum, the epiphytic species with the second highest IV in the present study, also has a wide distribution, extending from southern Mexico to the Atlantic Forest of southern Brazil (2012 Tropicos), being well adapted to various tropical environments such as caatinga (shrublands) cerrado (savanna) and restinga (Cotias-deOliveira et al. 1999). The species is referred to by Levey (1998) as a likely source of food for birds, which indicates its importance in the environment from the point of view of its ecological interactions and its role in seed dispersal.

The vascular epiphyte species composition differs among the restinga forests of the Algodoal-Maiandeua APA, as well as between those and other restinga forests in Brazil. This difference is expressed in the dominant species, dominant families and the prevailing functional groups. Despite the greater species richness observed for true epiphytes, the number of individuals was highest for hemiepiphytes. The vertical distribution was similar among the forests studied. However, there is no consensus regarding the other restinga forests of Brazil.

\section{Acknowledgments}

This study received financial support from the Brazilian Conselho Nacional de Desenvolvimento Científico e Tecnológico (CNPq, National Council for Scientific and Technological Development; Grant no. 561808/2010-4 for the project "Scientific research and local training as sustainable indicators for environmental restoration of the flora of the Algodoal-Maiandeua APA, Maracanã, Pará, Brazil”. The authors are grateful to the naturalist João Batista Ferreira for the assistance in the identification of orchids.

\section{References}

Amaral, D.D.; Prost, M.T.; Bastos, M.N.C.; Costa Neto, S.V. \& Santos, J.U.M. 2008. Restingas do litoral amazônico, estados do Pará e Amapá, Brasil. Boletim do Museu Paraense Emílio Goeldi. Ciências Naturais 3(1): 35-67.

Amaral, D.D.; Neto, S.V.C.; Rocha, A.E.S. \& Costa, D.C.T. 2009. Conservação da flora litorânea. Pp. 359-379. In: Jardim, M.A.G. (Org.). Diversidade biológica das áreas de proteção ambiental Ilhas do Combu e Algodoal-Maiandeua, Pará, Brasil. Belém, MPEG/MCT/ CNPq (Coleção Adolpho Ducke).
Bastos, M.N.C. \& Lobato, L.C.B. 1996. Estudos fitossociológicos em áreas de bosque de mangue na praia do Crispim e Ilha de Algodoal - Pará. Boletim do Museu Paraense Emílio Goeldi. Ciências da Terra 8: 157-167.

Bataghin, F.A.; Barros, F. \& Pires, J.S.R. 2010. Distribuição da comunidade de epífitas vasculares em sítios sob diferentes graus de perturbação na Floresta Nacional de Ipanema, São Paulo, Brasil. Revista brasileira de Botânica 33(3): 501-512.

Batista, F.J.; Jardim, M.A.G.; Medeiros, T.D.S. \& Lopes, I.L.M. 2011. Comparação florística e estrutural de duas florestas de várzea no estuário amazônico. Revista Árvore 35(2): 289-298.

Benavides, A.M.; Duque, M.A.J.; Duivenvoorder, J.F.; Vasco, G.A.J. \& Callajas, R. 2005. A first quantitative census of vascular epiphytes in rain forests of Colombian Amazonia. Biodiversity and Conservation 14: 739-758.

Benzing, D.H. 1990. Vascular epiphytes. New York, Cambridge University Press.

Benzing, D.H. 1986. The vegetative basis of vascular epiphytism. Selbyana 9: 23-43.

Bonnet, A. \& Queiroz, M.H. 2006. Estratificação vertical de bromélias epifíticas em diferentes estádios sucessionais da Floresta Ombrófila Densa, Ilha de Santa Catarina, Brasil. Revista brasileira de Botânica 29(2): 217-228.

Bonnet, A.; Curcio, G.R.; Lavoranti, O.J. \& Galvão, F. 2011. Flora epifítica vascular em três unidades vegetacionais do Rio Tibagi, Paraná, Brasil. Rodriguésia 62(3): 491-498.

Brown, D.A. 1990. El epifitismo en las selvas montanas del Parque Nacional "El Rey" Argentina: Composición florística y patrón de distribución. Revista de Biologia Tropical 38: 155-166.

Buzatto, C.R.; Severo, B.M.A. \& Waechter, J.L. 2008. Composição florística e distribuição ecológica de epífitos vasculares na Floresta Nacional de Passo Fundo, Rio Grande do Sul. Iheringia, série botânica 63(2): 231-239.

Ceja-Romero, J.; Mendoza-Ruiz, A.; López-Ferrari, A.R.; Espejo-Serna, A.; Pérez-García, B. \& García-Cruz, J. 2010. Las epífitas vasculares del estado de Hidalgo, México: diversidad y distribución. Acta Botânica Mexicana 93: 1-39.

Cervi, A.C. \& Borgo, M. 2007. Epífitos vasculares no Parque Nacional do Iguaçu, Paraná (Brasil). Levantamento preliminar. Fontqueria 55(51): 415-422.

Costa, J.M. 2009. As Pteridófitas. Pp.213-226. In: Jardim, M.A.G. (Org.). Diversidade biológica das áreas de proteção ambiental Ilhas do Combu e Algodoal-Maiandeua, Pará, Brasil. Belém, MPEG/MCT/ CNPq (Coleção Adolpho Ducke).

Cotias-de-Oliveira, A.L.P.; Guedes, M.L.S. \& Barreto, E.C. 1999. Chromosome Numbers For Anthurium And Philodendron SPP. (Araceae) Occurring In Bahia, Brazil. Genetics and Molecular Biology 22(2): 237-242.

Cunha, M.F.B. \& Forzza, R.C. 2007. Orchidaceae no Parque Natural Municipal da Prainha, RJ, Brasil. Acta Botanica Brasilica 21(2): 383-400.

Dejean, A.; Olmsted, I \& Snelling, R.R. 1995. Tree-Epiphyte-Ant Relationships in the Low Inundated Forest of Sian Kaan Biosphere Reserve, Quintana Roo, Mexico. Biotropica 27(1): 57-70.

Dettke, G.A.; Orfrini, A.C. \& Milaneze-Gutierre, M.A. 2008. Composição florística e distribuição de epífitas vasculares em um remanescente alterado de floresta estacional semidecidua no Paraná, Brasil. Rodriguésia 59(4): 859-872.

Fraga, C.N. \& Peixoto, A.L. 2004. Florística e ecologia das Orchidaceae das restingas do estado do Espírito Santo. Rodriguésia 55(84): 5-20.

Fraga, L.L.; Da Silva, L.B. \& Schmitt, J.L. 2008. Composição e distribuição vertical de pteridófitas epifíticas sobre Dicksonia sellowiana Hook. (Dicksoniaceae), em floresta ombrófila mista no sul do Brasil. Biota Neotropica 8(4): 123-129.

Gentry, A. \& Dodson, C.H. 1987. Diversity and biogeography of neotropical vascular epiphytes. Annals of the Missouri Botanical Garden 74: 205-233.

Giongo, C. \& Waechter, J.L. 2004. Composição florística e estrutura comunitária de epífitos vasculares em uma floresta de galeria na Depressão Central do Rio Grande do Sul. Revista Brasileira de Botânica 27(3): 563-57. 
Gonçalves, C.N. \& Waechter, J.L. 2002. Epífitos vasculares sobre espécimes de Ficus organensis isoladas no norte da planície costeira do Rio Grande do Sul: padrões de abundância e distribuição. Acta Botanica Brasilica 16(4): 429-441.

Gottsberger, G. \& Morawetz, W. 1993. Development and distribution of the epiphytic flora in an Amazonian savanna in Brazil. Flora 188: 145-151.

Hefler, S.M. \& Faustioni, P. 2004. Levantamento florístico de epífitos vasculares no Bosque São Cristovão-Curitiba-Paraná-Brasil. Estudos de Biologia 26(54): 11-19.

Jardim, M.A.G. \& Vieira, I.C.G. 2001. Composição florística e estrutura de uma floresta de várzea do estuário amazônico, ilha do Combu, Estado do Pará, Brasil. Boletim do Museu Paraense Emilio Goeldi, Série Botânica 17(2): 333-354.

Kersten, R.A. \& Silva, S.M. 2001. Composição florística e estrutura do componente epifítico vascular em Floresta da planície litorânea na Ilha do Mel, Paraná, Brasil. Revista brasileira de Botânica 24(2): 213-226.

Kersten, R.A. \& Silva, S.M. 2002. Florística e estrutura do componente epifítico vascular em Floresta Ombrófila Mista Aluvial do rio Birigui, Paraná, Brasil. Revista brasileira de Botânica 3(24): 259-267.

Kersten, R.A. 2006. Epifitismo vascular na Bacia do Alto Iguaçu, Paraná. Tese de Doutorado. Universidade Federal do Paraná, Curitiba.

Kersten, R.A. \& Kuniyoshi, Y.S. 2006. Epífitos vasculares na bacia do alto Iguaçu, Paraná-Composição florística. Estudos de Biologia 28: 55-71.

Kersten, R.A.; Borgo, M. \& Silva, M.S. 2009. Diversity and distribution of vascular epiphytes in an insular Brazilian coastal forest. Revista de Biologia Tropical 57(3): 749-759.

Kersten, R.A. 2010. Epífitas vasculares - História, participação taxonômica e aspectos relevantes com ênfase na Mata Atlântica. Hoehnea 37(1): 9-38.

Laube, S. \& Zotz, G. 2006. Neither host-specific nor random: vascular epiphytes on three tree species in a Panamanian lowland forest. Annals of Botany 97: 1103-1114.

Levey, D.J. 1998. Spatial and temporal variation in Costa Rican fruit and fruit-eating bird abundance. Ecological Monographs 58(4): 251-269.

Madison, M. 1977. Vascular epiphytes: their systematic occurrence and salient features. Selbyana 2: 1-13.

Mania, L.F. 2008. Florística e distribuição de epífitas vasculares em floresta alta de restinga na planície litorânea da praia da fazenda, núcleo- picinguaba, parque estadual Serra do Mar, Município de Ubatuba, SP. Dissertação de Mestrado. Universidade Estadual Paulista, Rio Claro.

Mania, L.F. \& Monteiro, R. 2010. Florística e ecologia de epífitas vasculares em um fragmento de floresta de restinga, Ubatuba, SP, Brasil. Rodriguésia 61(4): 705-713.

Martins, S.E.; Rossi, L.; Sampaio, P.S.P. \& Magenta, M.A.G. 2008. Caracterização florística de comunidades vegetais de restinga em Bertioga, SP, Brasil. Acta Botanica Brasilica 22(1): 249-274.

Maués, B.A.R.; Jardim, M.A.G.; Batista, F.J.; Medeiros, T.D.S. \& Quaresma, A.C. 2011. Composição floristica e estrutura do estrato inferior da floresta de várzea na Area de Proteção Ambiental Ilha do Combu, município de Belém, Pará. Revista Árvore 35(3): 669-677.

Mazella, L. \& Russo, G.F. 1989. Grazing effect of two Gibbula species (Molusca, Archaeogastropóda) on the epiphytic community of Posidonia oceanica leaves. Aquatic Botany 35(3-4): 357-373.

Medeiros, T.D.S. \& Quaresma, A.C. 2009. As Orquídeas. Pp: 71-77. In: Jardim, M.A.G. (org.), Diversidade biológica das Áreas de Proteção
Ambiental Ilhas do Combu e Algodoal-Maiandeua, Pará, Brasil. Belém, MPEG/MCT/CNPq (Coleção Adolpho Ducke).

Medeiros, T.D.S. \& Jardim, M.A.G. 2011. Distribuição vertical de orquídeas epífitas na Área de Proteção Ambiental (APA) Ilha do Combu, Belém, Pará, Brasil Revista brasileira de Biociências 9(1): 33-38.

Menezes, L.F.T.; Araujo, D.S.D. \& Nettesheim, F.C. 2010. Estrutura comunitária e amplitude ecológica do componente lenhoso de uma floresta de restinga mal drenada no sudeste do Brasil. Acta Botanica Brasilica 24(10): 825-839.

Nadkarni, N.M. 1984. Epiphyte biomass and nutrient capital of a neotropical elfin forest. Biotropica 16(4): 249-256.

Nadkarni, N.M. \& Matelson, T.J. 1989. Bird use of Epiphyte resources in neotropical trees. The Condor 91: 891-907.

Nieder, J.; Engwald, S.; Klawun, M. \& Barthlott, W. 2000. Spatial Distribution of Vascular Epiphytes (including Hemiepiphytes) in a Lowland Amazonian Rain Forest (Surumoni Crane Plot) of Southern Venezuela. Biotropica 32(3): 385-396.

Obermüller, F.A.; Silveira, M.; Salimon, C.I. \& Daly, D.C. 2012. Epiphytic (including hemiepiphytes) diversity in three timber species in the southwestern Amazon, Brazil. Biodiversity and Conservation 21:565-575.

Pos, E.T. \& Sleegers, A.D.M. 2010. Vertical distribution and ecology of vascular epiphytes in a lowland tropical rain forest of Brazil. Boletim do Museu Paraense Emílio Goeldi, Ciências Naturais 3(5): 335-344.

Quaresma, A.C. \& Medeiros, T.D.S. 2009. As bromélias. Pp.71-77. In M.A.G. Jardim (Org.), Diversidade biológica das Áreas de Proteção Ambiental Ilhas do Combu e Algodoal-Maiandeua, Pará, Brasil. Belém, MPEG/MCT/CNPq (Coleção Adolpho Ducke).

Quaresma, A.C. \& Jardim, M.A.G. 2012. Diversidade de bromeliáceas epífi tas na Área de Proteção Ambiental Ilha do Combu, Belém, Pará, Brasil. Acta Botanica Brasilica 26(2): 290-294.

Ribeiro, D.C.A. 2009. Estrutura e Composição de Epífitas Vasculares em duas formações vegetais na Ilha de Marambaia-Mangaratiba, RJ. Dissertação de Mestrado. Universidade Federal Rural do Rio de Janeiro, Rio de Janeiro.

Rogalski, J.M. \& Zanin, E.M. 2003. Composição florística de epífitos vasculares no estreito de Augusto César, Floresta Estacional Decidual do Rio Uruguai, RS, Brasil. Revista brasileira de Botânica 26(4): 551-556.

Sakuragui, C.M. 2001. Biogeografia de Philodendron seção Calostigma (Schott) Pfeiffer (Araceae) no Brasil. Maringá 23(2): 561-569.

Senna, C.S.F. \& Bastos, M.N.C. 2009. Caracterização dos gradiente florísticos. Pp.381-393. In: Jardim, M.A.G. (org.). Diversidade biológica das áreas de proteção ambiental Ilhas do Combu e AlgodoalMaiandeua, Pará, Brasil. Belém: MPEG/MCT/CNPq (Coleção Adolpho Ducke).

Tropicos.org. 2012. Missouri Botanical Garden. http://www.tropicos.org (acesso em 02/08/2012).

Waechter, J.L. 1998. Epifitismo vascular em uma floresta de restinga do Brasil subtropical. Revista Ciência e Natura 20: 43-66.

Wanderley, M.G.L.; Shepherd, G.J.; Melhem, T.S. \& Giulietti, A.M. 2007. Flora fanerogâmica do Estado de São Paulo. São Paulo, Instituto de Botânica.

Zotz, G. \& Schultz, S. 2007. The vascular epiphytes of a lowland forest in Panama - species composition and spatial structure. Plant Ecology 195: 131-141. 